Nevada

Environmental

Restoration

Project

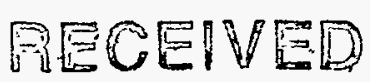

OCT 28 1S.3

OSTI
DOE/NV-452

UC-700

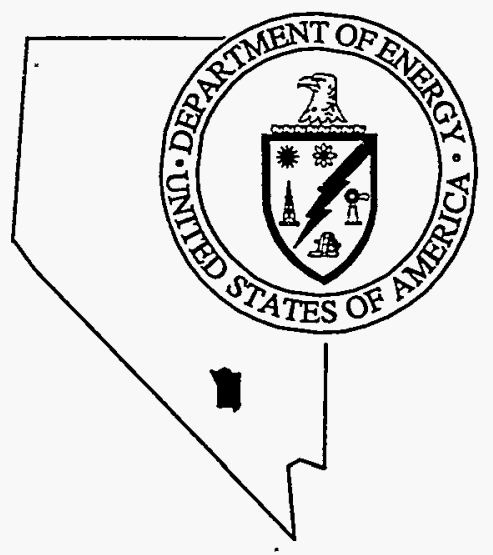

Housekeeping Category

Corrective Action Unit Work Plan

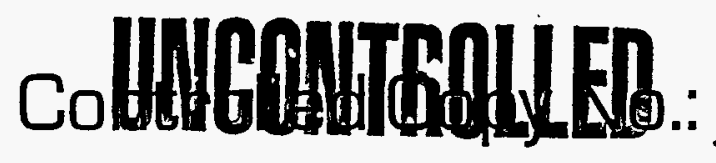

Revision: 0

August 1996

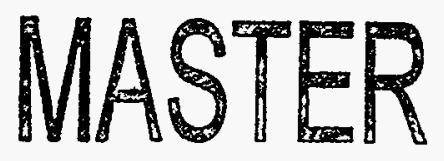

Environmental Restoration

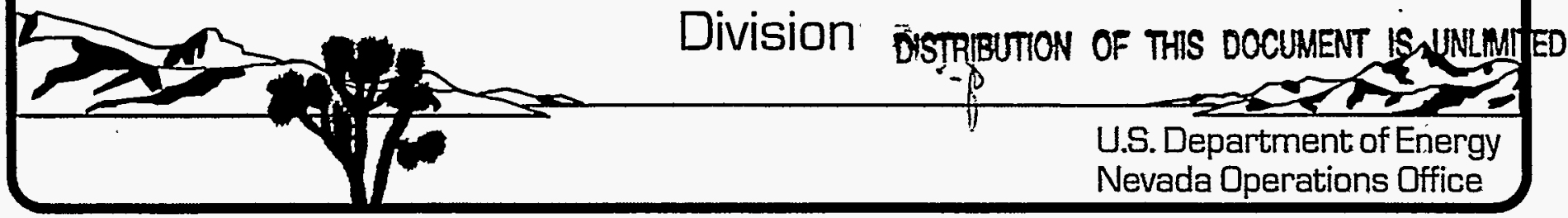


This report has been reproduced from the best available copy. Available in paper copy and microfiche.

Number of pages in this report: 36

DOE and DOE contractors can obtain copies of this report from: Office of Scientific and Technical Information, P.O. Box 62, Oak Ridge, TN 37831. (615) 576-8401.

This report is publicly available from the Department of Commerce, National Technical Information Service, 5285 Port Royal Road, Springfield, VA 22161. (703) 487-4650. 


\section{HOUSEKEEPING CATEGORY CORRECTIVE ACTION UNIT WORK PLAN}

DOE Nevada Operations Office

Las Vegas, Nevada

Revision: 0

August 1996 


\section{HOUSEKEEPING CATEGORY \\ CORRECTIVE ACTION UNIT WORK PLAN}

Approved by: Suirad Sedsen

Dave Bedsun, Director/Corrective Action Coordinator

Technical Compliance Division

Defense Special Weapons Agency

Approved by: Malect D. XRaper

Date: $.8 / 14 / 96$.

David S. Shafer, Acting Project Manager/

Corrective Action Coordinator

Nevada Environmental Restoration Project

DOE Nevada Operations Office

Date: $8 / i 9 / 96$ 


\section{DISCLAIMER}

Portions of this document may be illegible in electronic image products. Images are produced from the best available original document. 


\section{Table of Contents}

List of Figures $\ldots \ldots \ldots \ldots \ldots \ldots \ldots \ldots \ldots \ldots \ldots \ldots \ldots \ldots \ldots \ldots \ldots \ldots \ldots \ldots$

List of Tables $\ldots \ldots \ldots \ldots \ldots \ldots \ldots \ldots \ldots \ldots \ldots \ldots \ldots \ldots \ldots \ldots \ldots \ldots$

List of Acronyms and Abbreviations $\ldots \ldots \ldots \ldots \ldots \ldots \ldots \ldots \ldots \ldots \ldots \ldots \ldots$ iv

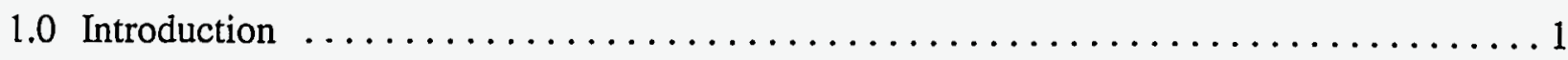

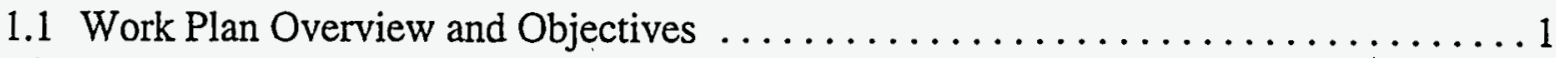

1.2 Housekeeping Category Corrective Action Sites Description . . . . . . . . . 2

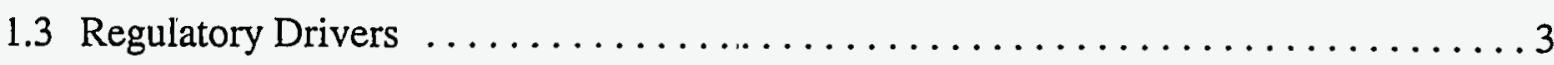

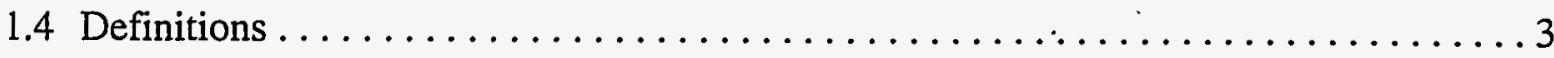

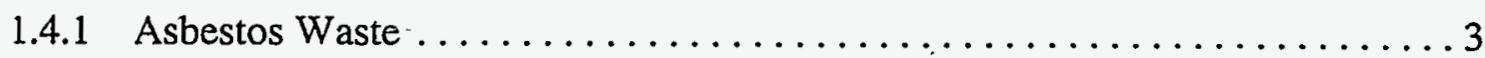

1.4.2 Controlled Waste Management Area $\ldots \ldots \ldots \ldots \ldots \ldots \ldots \ldots \ldots$

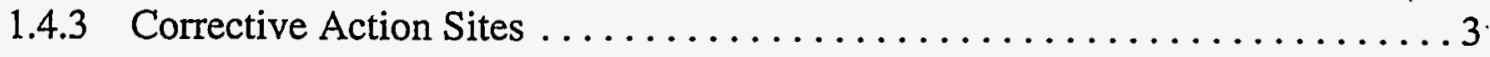

1.4.4 Corrective Action Units $\ldots \ldots \ldots \ldots \ldots \ldots \ldots \ldots \ldots \ldots \ldots \ldots$

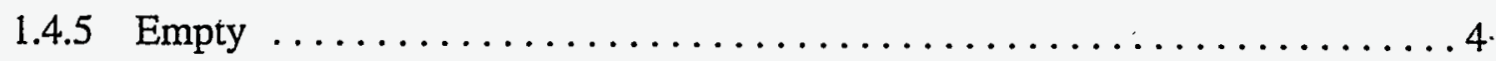

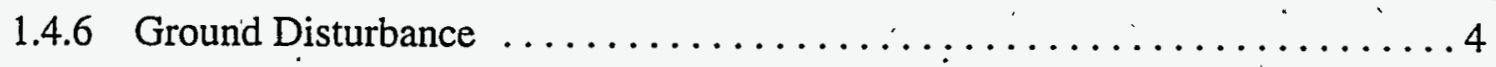

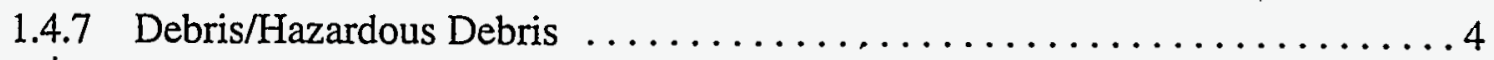

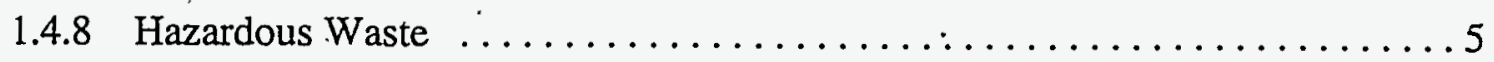

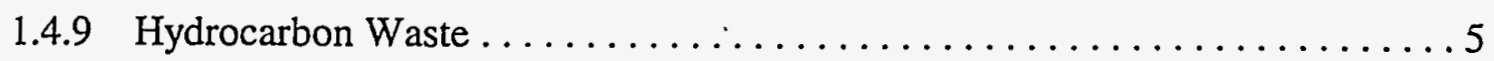

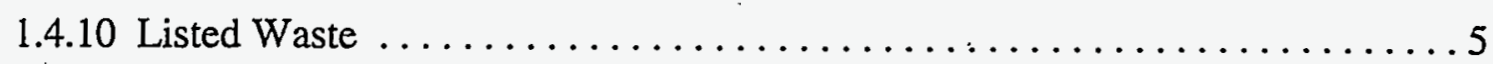

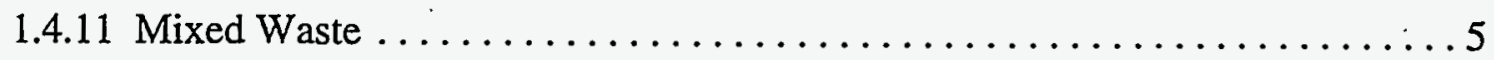

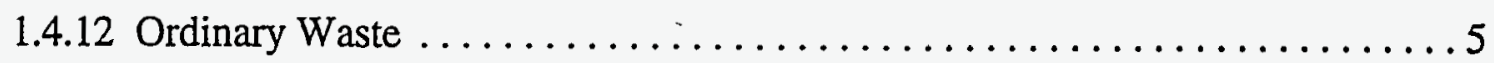

1.4.13 Polychlorinated Biphenyl Waste $\ldots \ldots \ldots \ldots \ldots \ldots \ldots \ldots \ldots \ldots \ldots \ldots \ldots \ldots \ldots$

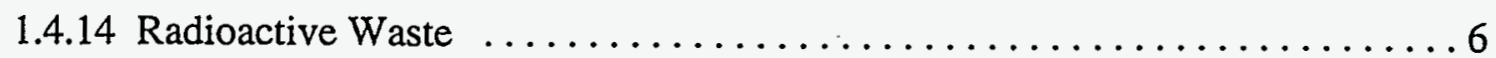

1.4.15 Recyclable/Salvageable Waste $\ldots \ldots \ldots \ldots \ldots \ldots \ldots \ldots \ldots \ldots \ldots$

1.4.16 Solid Waste Disposal Site . . . . . . . . . . . . . . . . . . . 6

2.0 Housekeeping Category Strategy $\ldots \ldots \ldots \ldots \ldots \ldots \ldots \ldots \ldots \ldots \ldots \ldots \ldots \ldots$

2.1 Determination of Corrective Action Process $\ldots \ldots \ldots \ldots \ldots \ldots \ldots \ldots \ldots \ldots$

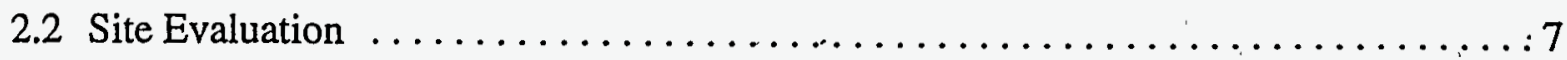

2.3 Waste Removal $\ldots \ldots \ldots \ldots \ldots \ldots \ldots \ldots \ldots \ldots \ldots \ldots \ldots \ldots \ldots \ldots$ 
2.3.1 Ordinary Waste $\ldots \ldots \ldots \ldots \ldots \ldots \ldots \ldots \ldots \ldots \ldots \ldots \ldots$

2.3.2 Recyclable or Salvageable Wastes $\ldots \ldots \ldots \ldots \ldots \ldots \ldots \ldots \ldots$

2.3.3 Debris/Hazardous Debris . . . . . . . . . . . . . . . . . 9

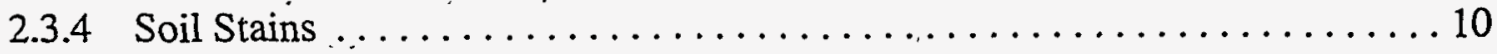

2.3.5 Hydrocarbon Waste . . . . . . . . . . . . . . . . . 10

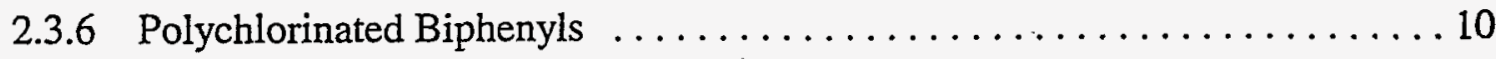

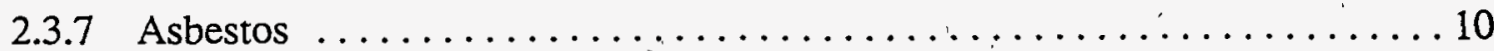

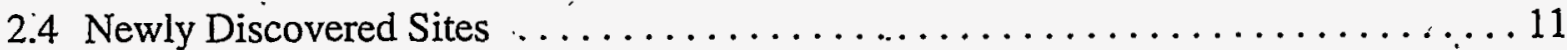

3.0 Housekeeping Category Corrective Action Documentation $\ldots \ldots \ldots \ldots \ldots \ldots$

4.0 Related Documents . . . . . . . . . . . . . . . . . . . . . . . . . 14

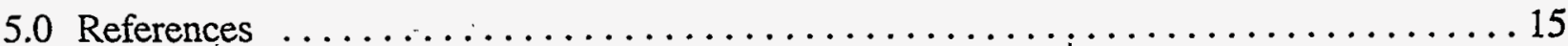

Appendix A - Waste Categorization List . . . . . . . . . . . . . . . . . 17

Appendix $B$ - Housekeeping Category Logic Diagrams $\ldots \ldots \ldots \ldots \ldots \ldots \ldots \ldots \ldots$

Appendix C - Example of a Housekeeping Category Corrective Action

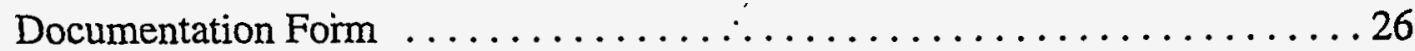




\section{List of Figures}

Number

Title

Page

B-1 Logic Diagram of Housekeeping Category Corrective Action Sites $\ldots \ldots \ldots \ldots 22$

B-2 Logic Diagram for Determination of Waste Category $\ldots \ldots \ldots \ldots \ldots \ldots \ldots 23$

B-3 Logic Diagram for Determination of Hazardous Waste $\ldots \ldots \ldots \ldots \ldots \ldots \ldots$

B-4 Logic Diagram for Evaluation of Potential Asbestos Waste $\ldots \ldots \ldots \ldots \ldots \ldots 25$

\section{List of Tables}

Number

Title

Page

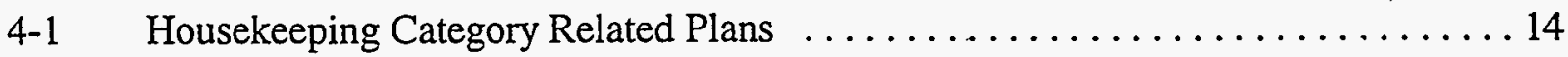

A-1 Waste Categorization List $\ldots \ldots \ldots \ldots \ldots \ldots \ldots \ldots \ldots \ldots \ldots \ldots \ldots \ldots \ldots \ldots \ldots \ldots$ 


\section{List of Acronyms and Abbreviations}

AEA

$\mathrm{BN}$

CAA

CAC

CAS

CAU

CFR

CWA

CWMA

DoD

DOE/NV

ERD ,

DSWA

FFACO

NDEP

NEPA

NTS

OSHA

PBMC

$\mathrm{PCB}$

POC

RCRA

RCT

REECo

SAFER

SOP

SWDS

TSCA

TTR

U.S.C.
Atomic Energy Act of 1954

Beçhtel Nevada

Clean Air Act

Corrective Action Coordinator

Corrective Action Site(s)

Correcrive Action Unit(s)

Code of Federal Regulations

Clean Water Act

Controlled Waste Management Area

U.S. Department of Defense

U.S. Department of Energy, Nevada Operations Office

Environmental Restoration Division

U.S. Defense Special Weapons Agency

Federal Facility Agreement and Consent Order

Nevada Division of Environmental Protection

National Environmental Policy Act

Nevada Test Site

Occupational Safety and Health Act

Performance-Based Management Contractor

Polychlorinated biphenyl(s)

Performance Objective Certification

Resource Conservation and Recovery Act

Radiological Control Technician .

Reynolds Electrical \& Engineering Co., Inc.

Streamlined Approach for Environmental Restoration

Standard Operating Procedure(s)

Solid Waste Disposal Site

Toxic Substances Control Act

Tonopah Test Range

United States Code 


\subsection{Introduction}

The purpose of this Corrective Action Unit (CAU) Work Plan is to provide a strategy to be used by the U.S. Department of Energy Nevada Operations Office (DOE/NV), the U.S. Department of Defense (DoD) Defense Special Weapons Agency (DSWA) (formerly the Defense Nuclear Agency), and contractor personnel for conducting corrective actions at the Nevada Test Site (NTS) and Nevada off-site locations including the Tonopah Test Range (TTR), the Project Shoal Area, and the Central Nevada Test Area. This Work Plan applies to housekeeping category CAUs already listed in the Federal Facility Agreement and Consent Order (FFACO) Appendices (FFACO, 1996) as well as newly identified Corrective Action Sites (CASs) that will follow the housekeeping process.

This Work Plan represents a joint effort between DOE/NV and DSWA to implement the identification and description of existing or new housekeeping category CASs, the corrective actions performed at these sites, documentation of housekeeping activities, and housekeeping site closure. This CAU Work Plan should be used in accordance with Appendix VI of the FFACO, the "Corrective Action Strategy" (FFACO, 1996).

\subsection{Work Plan Overview and Objectives}

Housekeeping category introductory information, objectives, and definitions are presented in Section 1.0 of this Work Plan. In Section 2.0, the housekeeping process is described as it relates to various waste types and the guidance set forth in the FFACO. Section 2.0 also contains discussion on the recognition and categorization of various waste types (i.e., housekeeping category wastes versus Streamlined Approach for Environmental Restoration [SAFER] or . Complex process wastes). Housekeeping category corrective action documentation is described in Section 3.0, and the relevant plans and related documents to be considered and/or used in conjunction with this Work Plan are described in Section 4.0. In Section 5.0, the references associated with this Work Plan are presented.

The housekeeping process provides a uniform guidance for waste removal and disposal. A uniform approach ensures that written records and photographic documentation of corrective action activities are recorded in a consistent manner, that the recorded information will satisfy the data requirements to achieve regulatory approval for site closure, that the waste removal and 
disposal information is consistent with and supportive of a determination of clean closure (i.e., no further action), and that all corrective actions comply with applicable regulations.

The specific objectives of this Work Plan are to provide guidance for:

- Determining whether newly discovered waste material constitutes a new CAS and/or is amenable to a housekeeping process corrective action

- Conducting corrective actions according to the housekeeping process as outlined in the -FFACO "Corrective Action Strategy" (FFACO, 1996)

- Documenting corrective actions at housekeeping category CASs

- Coordinating contractor efforts to avoid duplication and ensure continuity and traceability of waste removal and disposal actions on a site-specific basis

- Obtaining regulatory approval of CAS/CAU closure with no further action needed.

\subsection{Housekeeping Category Corrective Action Sites Description}

As specified in the "Corrective Action Strategy" (FFACO, 1996), the housekeeping corrective action process is used for CASs that do not require further investigation prior to completing the corrective action. Housekeeping CASs may only be closed through clean closure. At these CASs, historical and field verification data sanction the removal of discarded material and/or directly impacted soils and the conduct of confirmatory sampling (if necessary), without additional investigation. Documentation of the waste removal and any confirmatory sampling is provided in a closure report.

Examples of waste types for which corrective actions may be performed using the housekeeping process are listed in Appendix A. Waste types not eligible for corrective action under this CAU Work Plan include low-level radioactive waste and friable asbestos waste. In addition, because mixed waste is not addressed by the FFACO, it is also excluded from this Work Plan.

Because housekeeping-category wastes are widespread at the NTS and other locations, addition of every newly identified waste item to the FFACO appendices would not be practical or efficient. Therefore, newly identified trash, litter, rubbish, and debris, when not associated with visible staining and when not located in a known contamination area, will not constitute new CASs. Examples of waste types which will not be marked as new CASs include ordinary wastes as listed in Appendix A. Instead, these waste types will be noted and tallied on weight tickets or 
other related field documentation by the waste removal crews. It should be noted that newly identified lead materials are considered new CASs.

\subsection{Regulatory Drivers}

The FFACO (1996), signed by the DOE, Nevada Division of Environmental Protection (NDEP), and $\mathrm{DoD}$, is the primary regulatory driver for conducting corrective actions at the NTS and DOE/NV off-site locations. Additional drivers for these sites include federal and state laws and regulations as well as state policies and DOE Orders.

\subsection{Definitions}

The following definitions should be considered with regard to housekeeping category sites.

\subsubsection{Asbestos Waste}

Asbestos-containing waste is subject to special regulations for handling, transport, and disposal under the Occupational Safety and Health Act (OSHA) regulations, the Toxic Substances Control Act (TSCA), and the National Emissions Standards for Hazardous Air Pollutants (Environmental Statutes, 1988). Asbestos can be identified through process knowledge or by collecting a sample and analyzing that sample by microscopy, and only personnel licensed as asbestos inspectors by

- the State of Nevada may collect asbestos samples. Friable asbestos-containing waste must be wetted, double-bagged, and double-labeled prior to transport, and it must be disposed of in a special section of a licensed sanitary landfill.

\subsubsection{Controlled Waste Management Area}

A Controlled Waste Management Area (CWMA) is an area in which the potential exists for contamination due to the presence of unencapsulated or unconfined radioactive material, or it is an area that is exposed to beams or other sources of particles capable of causing activation, i.e., neutrons and protons. Controlled Waste Management Areas also include any other posted Radiological Area (BN, 1995).

\subsubsection{Corrective Action Sites}

Corrective Action Sites are those sites potentially requiring correction action(s) and may include solid waste management units or individual disposal or release sites (FFACO, 1996). 


\subsubsection{Corrective Action Units}

Corrective Action Units consist of one or more CASs grouped geographically, by technical similarity, by agency responsibility, or other appropriate reasons for the purpose of determining corrective actions (FFACO, 1996).

\subsubsection{Empty}

A container or inner liner removed from a container that has held any hazardous substance (except compressed gas or an acute hazardous waste) is empty (as per Title 40 Code of Federal Regulations [CFR] Part 261, Identification and Listing of Hazardous Waste [CFR, 1992]) if: (1) all waste has been removed that can be removed using common practice and no more than 2.5 centimeters of residue remain on the bottom of the container or inner liner, or (2) no more than 3 percent by weight of the total capacity of the container remains in the container or inner liner if the container is less than, or equal to, 110 gallons in size ( 0.3 percent by weight if greater than 110 gallons). A container that held a compressed gas is empty when the pressure in the container approaches atmospheric. The container or the inner liner removed from a container that held an acute hazardous waste is empty if the container or inner liner has been triple rinsed or if the inner liner that prevented contact of the product with the container has been removed and the rinsate is retained as a hazardous waste.

\subsubsection{Ground Disturbance}

Ground disturbances include any activity which disrupts or damages plant or animal habitats or cultural resources. Ground disturbances do not include removal of less than 2.3 cubic meters (81 cubic feet or 3 cubic yards) of soil contaminated with known materials provided plant and/or animal habitats or cultural resources are not disturbed.

\subsubsection{Debris/Hazardous Debris}

Debris is solid material exceeding a 60 -millimeter particle size that is intended for disposal and that is a manufactured object, plant or animal matter, or natural geologic material. Hazardous debris contains a hazardous waste listed in Title 40 CFR Part 261 Subpart D "Lists of Hazardous Wastes" (CFR, 1992) or exhibits a characteristic (ignitability, corrosivity, reactivity, or toxicity) of hazardous waste identified in Title 40 CFR Part 261 Subpart C "Characteristics of Hazardous Waste" (CFR, 1992). 


\subsubsection{Hazardous Waste}

A waste or combination of wastes that because of quantity, concentration, toxicity, corrosiveness, flammability, reactivity, or physical, chemical, or infectious characteristic may cause harm to human health or the environment, as specified in 42 United States Code (U.S.C.)

Section 6903 (5) (Solid Waste Disposal Act, 1976) is considered hazardous. Hazardous waste may be listed, characteristic, or so deemed by the State of Nevada in Nevada Revised Statute 459.430 (State of Nevada, 1991) and Title 40 CFR Part 261 (CFR, 1992).

\subsubsection{Hydrocarbon Waste}

Hydrocarbon waste is a waste consisting of petroleum hydrocarbons. Process knowledge or sampling must be used to determine which regulations are applicable to hydrocarbon waste (such as stained soil).

\subsubsection{Listed Waste}

Listed wastes are those cited in Title 40 CFR Part 261 (CFR, 1992) on one of four lists: F, K, P, or U. The F-list wastes are nonprocess-specific "used" wastes. K-listed wastes are processspecific "used" wastes. P- and U-listed wastes are commercial chemical products and spill residues as identified in Title 40 CFR 261.33 (CFR, 1992). Combinations of any listed hazardous waste with other non-hazardous waste will result in the same listed hazardous waste.

\subsubsection{Mixed Waste}

Mixed waste contains both radioactive and hazardous components regulated by the Atomic Energy Act of 1954 (AEA) and the Resource Conservation and Recovery Act (RCRA) (Environmental Statutes, 1988), respectively, per 42 U.S.C. Section 6903 (41) (Solid Waste Disposal Act, 1976).

\subsubsection{Ordinary Waste}

Ordinary waste is any discarded, nonradioactive material that is identified as garbage, sewage, rubbish, refuse, or sludge, or is excluded by Title 40 CFR Part 261 (CFR, 1992). Ordinary waste includes industrial, commercial, and solid household-type wastes, and excludes non-recyclable, hazardous, radioactive, polychlorinated biphenyl (PCB), asbestos, or mixed wastes. 


\subsubsection{Polychlorinated Biphenyl Waste}

Polychlorinated biphenyls are one of several compounds that are produced by replacing hydrogen atoms in biphenyl with chlorine, have various industrial applications, and are poisonous environmental pollutants which tend to accumulate in animal tissues. Waste containing polychlorinated biphenyls is regulated for handling, transport, storage, and disposal under the TSCA. Capacitors, fluorescent light ballasts, and transformers are examples of equipment that may contain PCBs.

\subsubsection{Radioactive Waste}

Solid, liquid, or gaseous material that contains radionuclides regulated under the AEA, as amended, and which is of negligible economic value considering cost of recovery, is considered to be radioactive waste (DOE Order 5820.2A, Radioactive Waste Management [DOE, 1995a]).

\subsubsection{Recyclable/Salvageable Waste}

Recyclable and salvageable wastes are able to be returned to an original condition so that the material is adaptable to a new use or reuse. Hazardous waste may be recycled; ordinary waste may be salvaged.

\subsubsection{6 . Solid Waste Disposal Site}

A solid waste disposal site (SWDS) is a system for disposal of refuse, garbage, rubbish, and - industrial solid waste in compacted layers covered with soil to a depth sufficient to exclude rats, flies, and other disease vectors. 


\subsection{Housekeeping Category Strategy}

Housekeeping category waste removal, waste disposition, and confirmatory sampling will be performed in accordance with this Work Plan and related documents as discussed in Section 4.0. Documentation of the waste removal and confirmatory sampling will be through a closure report for which sufficient supporting documentation has been gathered. The closure report shall follow the guidelines set forth in the Work Plan for Closure Verification of FFACO Corrective Action Sites/Units (DOE/DoD, 1996). If a housekeeping CAS proves more complex than anticipated, such as finding an unexpected waste type, the CAS will be recommended for inclusion into a different CAU and may not be treated thereafter by this Work Plan.

\subsection{Determination of Corrective Action Process}

After waste is discovered, it must be confirmed that the housekeeping process is correct for the CAS. Figure B-1 is a flowchart illustrating this confirmation strategy. If corrective actions at a site cannot be conducted using the housekeeping process, that CAS cannot be part of the housekeeping CAU. Regrouping of the errant CAS into a different CAU will be initiated by DOE or DSWA. Provided the written documentation supports reassignment, NDEP approval of the proposed transfer will then occur at the subsequent FFACO quarterly meeting. The CAS may then be re-evaluated under the SAFER or Complex process.

\subsection{Site Evaluation}

Prior to any removal of waste from CASs under the housekeeping process, the following activities will be completed:

- Field screening for radioactive contamination and other hazards as required under the DOE/NV Environmental Restoration Division (ERD) Health and Safety Plan (DOE, 1994b).

- Site evaluation of new or previously unevaluated sites including site location and waste description documentation for all materials within a 3-meter (10-foot) radius of the site center, acquisition of site coordinates and photograph(s), placement of a site marker, and completion of applicable documentation.

\subsection{Waste Removal}

At the NTS, a Radiological Control Technician (RCT) will accompany field crews during corrective action operations. At off-site locations, RCTs will be present, as needed, based on 
site-specific conditions. At each applicable CAS, waste will be surveyed and cleared by the RCT and issued a radiation clearance certification (i.e., green tag) prior to removal. The survey shall include field screening and/or collecting swipe samples to determine if contamination is present and removable. Screening data collected from nonradiological areas should be evaluated against the requirements of Title 10 CFR Part 835, Occupational Radiation Protection (CFR, 1994) as supplemented by the NTS Radiation Protection Program (DOE, 1995b). In CWMAs, the Performance Objective Certification (POC) guidance (BN, 1995) shall be used to evaluate sitescreening results, and any waste containing isotopes not addressed in, or exceeding the NTS POC screening levels, shall be managed as radioactive waste (i.e., not housekeeping) in accordance with the requirements of DOE Order 5820.2A (DOE, 1995a) and NVO-325, Nevada Test Site Defense Waste Acceptance Criteria, Certification and Transfer Requirements (DOE, 1992).

During corrective actions, if dust control is required, if a protected habitat will be disturbed, or if a ground disturbance will be created using anything larger than a hand-held shovel or small, rubber-tired equipment, the CAS is not eligible for the housekeeping category. In order to determine if waste removal operations may cause a ground disturbance, the following should be completed prior to corrective action:

- Inspection of sites located in desert tortoise areas for tortoise habitat and for other endangered species as per DOE Order'54XC.1B, Threatened and Endangered Species Protection (DOE, 1994c)

- Evaluation of the need for a Cultural Resource Survey in accordance with DOE Order NV 54XD.1B, Protection of Cultural Resources (DOE, 1994d)

- Evaluation of the need for National Environmental Policy Act (NEPÁ) (Environmental Statutes, 1988) documentation (i.e., a generic Categorical Exclusion)

During corrective action operations, readily removable waste will be segregated by waste type and transported to the proper disposal/collection site based on the waste categorization. In conjunction with these activities, the following shall be completed:

- A Housekeeping Category Corrective Action Documentation Form (see Section 3.0 and Appendix C) or comparable documentation for each CAS

- Photographic documentation of waste removal operations

- Waste disposal documentation as appropriate (e.g., Bills of Lading, manifests) 
- Verification that corrective actions are complete for all sites in the CAU (per the Work Plan for Closure Verification of FFACO Housekeeping C.orrective Action Sites/Units. [DOE/DoD. 1996])

- A closure report with all necessary documentation submitted to NDEP (per DOE/DoD, 1996)

A discussion of specific waste categories and the disposal practices for each are presented in the following sections. A logic diagram for waste category determination is presented in Figure B-2.

\subsubsection{Ordinary Waste}

Examples of ordinary waste are indicated in Appendix A. Ordinary waste will be transported to . either the Area 9 U-10c Class II SWDS, or to the Area 23 Class II SWDS. A radiological clearance certification will be issued for the ordinary waste, and the material will be tracked to its destination with a Bill of Lading, or equivalent documentation. At the NTS, household waste, sludge, and industrial solid wastes are accepted only at the Area 23 SWDS.

\subsubsection{Recyclable or Salvageable Wastes}

Recyclable or salvageable wastes include those materials that may be reused or sold. Examples of items acceptable for recycling or salvage are listed in Appendix A.

Recyclable and salvageable waste that is not radioactively contaminated may be removed from the site provided that a ground disturbance will not be created. Materials which have been identified as either recyclable or salvageable will be transported to the proper collection point (e.g., intact, lead acid batteries to one of the collection points established by the PerformanceBased Management Contractor [PBMC]). A mobile satellite accumulation area (e.g., a drum which is moved from site to site until full) may be used to compile recyclable or scrap materials from multiple CASs. A radiological clearance certification will be issued for these materials which will be tracked to their destination with a Bill of Lading or equivalent documentation.

\subsubsection{Debris/Hazardous Debris}

Based on process knowledge, a waste categorized as hazardous debris may be removed and disposed under the housekeeping category, with the exception of geologic materials that may exhibit a hazardous characteristic (see Section 1.4.7). The following materials are considered to be hazardous debris: lead acid batteries, cadmium batteries, lead solids, intact fluorescent tubes, 
and mercury vapor lamps. A radiological clearance certification will be issued for these materials.

\subsubsection{Soil Stains}

Soil stains of known materials or which have been characterized before prioritization may be remediated under the housekeeping category provided the volume of impacted soil is less than 2.3 cubic meters ( 81 cubic feet or 3 cubic yards). Confirmatory sampling will be required. At housekeeping CASs, one confirmatory sample may be collected to verify completion of corrective actions. If more than one confirmatory sample is anticipated, the CAS is no longer applicable in the housekeeping category.

\subsubsection{Hydrocarbon Waste}

Process knowledge or sampling must be used to determine how hydrocarbon waste, such as stained soil, is regulated. Items contaminated solely with certain petroleum hydrocarbons (such as diesel fuel, motor oil, or lubrication oil) are not hazardous waste but must be disposed of in a special section of a SWDS or at the NTS Area 6 Hydrocarbon Landfill. Hydrocarbon spills impacting greater than 2.3 cubic meters ( 81 cubic feet or 3 cubic yards) of soil are not housekeeping category sites.

\subsubsection{Polychlorinated Biphenyls}

All unlabeled electrical equipment that may contain liquids will be assumed to contain regulated quantities of PCBs until sampling and analysis has demonstrated that the equipment is non-PCB or until examination has determined that the equipment contains no oil or other fluids. Polychlorinated biphenyls in a container with a capacity of less than one gallon may be considered a housekeeping category CAS; however, uncontained, spilled, or burned PCBs are not housekeeping CASs. Ballasts containing PCBs, if not accumulated, can be disposed of at a SWDS. However, PCB ballasts which have been accumulated must be characterized and are therefore not housekeeping waste. Refer to Figure B-3 for information about the categorization of PCB waste.

\subsubsection{Asbestos}

Only non-friable asbestos may be removed and disposed of as housekeeping category waste. Friable.(i.e., easily crumbled) asbestos must be evaluated under the SAFER or Complex process. A logic diagram for evaluation of potential asbestos waste is shown in Figure B-4. 


\subsection{Newly Discovered Sites}

When a potential new CAS is discovered during ongoing clean-up activities, corrective actions may be performed at the time of discovery provided the site may be categorized as housekeeping in accordance with this Work Plan. One objective of the housekeeping process is to minimize the addition of new FFACO sites. Tracking of corrective actions at such sites will be through field documentation such as Housekeeping Category Corrective Action Documentation Forms (Appendix C), Bills of Lading, etc. These sites will not be listed in the FFACO and do not require additional documentation:

When a potential new CAS is discovered, and corrective actions cannot be implemented at the time of discovery and/or under this Work Plan, the potential CAS will be evaluated for inclusion in Appendix II or Appendix III of the FFACO by the appropriate Corrective Action Coordinator (CAC). The process for adding a potential new CAS is as follows:

- The DOE Environmental Restoration Division (ERD) CAC or the DSWA CAC is notified by letter of the potential new CAS.

- DOE or DSWA determines whether corrective actions may be performed in accordance with this Work Plan or whether the potential CAS should be added to the FFACO Appendices.

- If corrective actions may be conducted in accordance with this Work Plan, the site will be turned over to the DOE/NV PBMC for further action and will not be added to the FFACO Appendices. Tracking of corrective action activities will be through field documentation as discussed above.

- If corrective actions cannot be conducted in accordance with this Work Plan, the site constitutes a new CAS and should be added to the FFACO Appendices.

- If the potential CAS has already been reported to the NDEP under a mechanism other than the FFACO (e.g., a tank notice), and if the waste was generated at this site prior to the signing of the FFACO (May 10, 1996), the CAS must be added to an FFACO Appendix regardless of whether corrective actions may be performed in accordance with this Work Plan.

- If the new CAS must be added to the FFACO, signed documentation approving the addition of the CAS to a CAU within Appendix II or III of the FFACO is forwarded to the DOE/NV FFACO Data Repository Manager. 
- The FFACO Data Repository Manager adds the new CAS to Appendix II or III, incorporating it into the designated CAU.

- The updated Appendix II or Appendix III is presented at the next FFACO quarterly meeting. 


\subsection{Housekeeping Category Corrective Action Documentation}

Corrective actions at housekeeping sites will be recorded in a project log book or an equivalent log each day that corrective action-related activities take place. In addition; a Housekeeping Category Corrective Action Documentation Form (Appendix C) will be completed for each CAS. This form standardizes the information recorded for waste removal activities and ensures that waste disposal documentation such as Bills of Lading, manifests (both on and offsite), and other disposal records become part of the record of progression of the CAS to Appendix IV of the * FFACO (FFACO, 1996). As per the FFACO, all related documentation, including confirmatory sampling results, shall be established and maintained in accordance with DOE and DoD records retention procedures.

A Closure Report will be prepared for each CAU in accordance with the Work Plan for Closure Verification of FFACO Housekeeping Corrective Action Sites/Units (DOE/DoD, 1996). Once corrective actions at all CASs within a specified CAU are completed, a Closure Report will be compiled and submitted to NDEP for approval. Once NDEP issues a Notice of Completion approving the CAU closure, the CAU will be transferred to Appendix IV of the FFACO. If an NDEP Notice of Completion is not received, the corrective action approach for the specified CAU should be reevaluated according to the "Corrective Action Strategy" as per Appendix VI of the FFACO (FFACO, 1996). 


\subsection{Related Documents}

Corrective actions at housekeeping category sites shall be conducted under existing umbrella documents for quality assurance, health and safety, waste management, and sampling. Examples of these documents are listed in Table 4-1. Other pertinent documents may include Work Plans (e.g., DOE/DoD, 1996); contractor-specific operating procedures; site-specific health and safety plans; and field instructions as applicable.

Table 4-1

Housekeeping Category Related Plans

\begin{tabular}{||l|l|l||}
\hline \multicolumn{1}{|c|}{ Topic } & \multicolumn{1}{|c|}{ Applicable Plans } & \multicolumn{1}{|c|}{$\begin{array}{c}\text { Applicable } \\
\text { Location(s) }\end{array}$} \\
\hline Quality Assurance & $\begin{array}{l}\text { Resource Conservation and Recovery Act } \\
\text { Industrial Sites Quality Assurance Project Plan, } \\
\text { Nevada Test Site, Nevada (DOE, 1994a) }\end{array}$ & NTS, TTR, Offsites \\
\hline Health and Safety & $\begin{array}{l}\text { DOE/NV Environmental Restoration Division } \\
\text { Health and Safety Plan (DOE, 1994b) }\end{array}$ & NTS, TTR, Offsites \\
\cline { 2 - 4 } Waste Management & $\begin{array}{l}\text { NTS Radiation Protection Program } \\
\text { (DOE, 1995b) }\end{array}$ & NTS, TTR, Offsites \\
\cline { 2 - 4 } & $\begin{array}{l}\text { Waste Characterization Sampling and Analysis } \\
\text { Plan for TTR (IT, 1996) }\end{array}$ & TTR \\
\hline $\begin{array}{l}\text { Nevada Test Site Performance Objective for } \\
\text { Certification of Nonradioactive Hazardous } \\
\text { Waste (BN, 1995) }\end{array}$ & NTS \\
\cline { 2 - 4 } & $\begin{array}{l}\text { Solid Waste Disposal Site Operations and } \\
\text { Maintenance Plans (BN, 1996; REECo, 1993; } \\
\text { REECo, 1995) }\end{array}$ & NTS \\
\hline Confirmation & $\begin{array}{l}\text { CAS-Specific Sampling and Analysis Plans } \\
\text { (developed as needed) }\end{array}$ & NTS, TTR, Offsites \\
\hline
\end{tabular}




\subsection{References}

Bechtel Nevada. 1995. Nevada Test Site Performance Objective for Certification of Nonradioactive Hazardous Waste. December 18, 1995. Las Vegas, NV.

Bechtel Nevada. 1996. Operating Plan for U10C Solid Waste Disposal Site (Class II). January, 1996. Las Vegas, NV.

BN (see Bechtel Nevada).

CFR (see Code of Federal Regulations).

Code of Federal Regulations. 1992. Title 40 CFR Part 261. Identification and Listing of Hazardous Waste. July 1, 1992. Washington, DC: U.S. Government Printing.

Code of Federal Regulations. 1994. Title 10 CFR Part 835. Occupational Radiation Protection, Final Rule. U.S. Department of Energy. January 1, 1994. Wașington, DC:

U.S. Government Printing.

DOE (see U.S. Department of Energy).

DOE/NV (see U.S. Department of Energy, Nevada Operations Office).

Environmental Statutes. 1988. Rockville, MD: Government Institutes, Inc.

Federal Facility Agreement and Consent Order (FFACO) of 1996. 1996. Prepared by the . Nevada Division of Environmental Protection, the U.S. Department of Energy, and the U.S. Department of Defense.

IT (see IT Corporation).

IT Corporation. 1996. Waste Characterization Sampling and Analysis Plan for Tonopah Test Range: Corrective Action Units 400, 407, 426, 430, and the Wind Radar Antenna Pedestal, ITLV/NV10972-168. Las Vegas, NV.

REECo (see Reynolds Electrical \& Engineering Co., Inc.).

Reynolds Electrical \& Engineering Co., Inc. 1993. Operation and Maintenance Plan for the Nevada Test Site Class I Landfills in Areas 9 and 23. February, 1993. Las Vegas, NV.

Reynolds Electrical \& Engineering Co., Inc. 1995. Operation and Maintenance (O\&M) Plan for the Nevada Test Site (NTS) Area 6 Class III Disposal Site for the Disposal of HydrocarbonBurdened Soil, Septic Sludge and Debris. Revised July, 1995. Las Vegas, NV. 
Solid Waste Disposal Act. U.S. Code. 1976. Vol. 42, Section 6903.

State of Nevada. 1991. Nevada Revised Statute 459.430, Nevada Hazardous Waste Disposal Law. "Hazaräous Waste Defined." The Bureau of National Affairs, Inc. Washington, DC.

U.S. Department of Energy, Nevada Operations Office. 1992. Nevada Test Site Defense Waste Acceptance Criteria, Certification, and Transfer Requirements, NVO-325, Rev. 1. Las Vegas, NV.

U.S. Department of Energy, Nevada Operations Office. 1994a. Resource Conservation and Recovery Act Industrial Sites Quality Assurance Project Plan, Nevada Test Site, Nevada, Rev. O. Las Vegas, NV.

U.S. Department of Energy, Nevada Operations Office. 1994b. Environmental Restoration Division Health and Safety Plan, Rev. 1. Las Vegas, NV.

U.S. Department of Energy, Nevada Operations Office. 1994c. DOE Order NV 54XC.1B, Threatened and Endangered Species Protection. Las Vegas, NV.

U.S. Department of Energy, Nevada Operations Office. 1994d. DOE Order NV 54XD.1B, Protection of Cultural Resources, September 14, 1994. Las Vegas, NV.

U.S. Department of Energy, Nevada Operations Office. 1995a. DOE Order 5820.2A, Radioactive Waste Management. Las Vegas, NV.

U.S. Department of Energy, Nevada Operations Office. 1995b. Nevada Test Site Radiation Protection Program. DOE/NV/11432-203, UC-702. Rev. 3. December 1995. Las Vegas, NV.

U.S. Department of Energy; Nevada Operations Office and the U.S. Department of Defense, Defense Special Weapons Agency. 1996. Work Plan for Closure Verification of FFACO Housekeeping Corrective Action Sites/Units. Las Vegas, NV. 
Housekeeping CAU Work Plan

Revision: 0

Date: 08/19/96

Page 17 of 30

\section{Appendix A}

\section{Waste Categorization List}


Table A-1

Waste Categorization List (Page 1 of 3 )

\begin{tabular}{|c|c|}
\hline Waste Type & Possible Waste Category \\
\hline Abandoned chemicals & Not housekeeping \\
\hline Aerosol cans & $\begin{array}{l}\text { Housekeeping if empty or if not empty but contents } \\
\text { are identifiable by process knowledge }\end{array}$ \\
\hline Air filters & Ordinary waste. \\
\hline Aluminum cans & Salvageable \\
\hline Arsenic & Contained in pesticides; not housekeeping \\
\hline Asbestos (non-friable) & Ordinary \\
\hline Bare wood, wooden structures & Ordinary waste \\
\hline Batteries - lead acid (intact) & Recyclable \\
\hline Batteries - lead acid (crushed) & Hazardous \\
\hline Batteries, other - intact & $\begin{array}{l}\text { Recyclable except alkaline, mercury, or nickel- } \\
\text { cadmium }\end{array}$ \\
\hline Black rubber casing & Ordinary waste \\
\hline Bottles & Ordinary waste \\
\hline Buckets or Cans (empty) & Ordinary waste \\
\hline Buckets or Cans (not empty) & $\begin{array}{l}\text { Hazardous or salvageable; not housekeeping unless } \\
\text { contents are known }\end{array}$ \\
\hline Cable and wire & Salvageable if in good condition; otherwise ordinary \\
\hline Cadmium & Paint and batteries may contain; not housekeeping \\
\hline Capácitors & May contain PCBs \\
\hline Chromium & May be present in paint; not housekeeping \\
\hline Circuit and electrical boxes & Salvageable or recyclable (if in good condition) \\
\hline Concrete blocks, cinder blocks & Salvageable if not broken; otherwise ordinary waste \\
\hline $\begin{array}{l}\text { Construction debris (untreated lumber, rebar, or } \\
\text { concrete) }\end{array}$ & Industrial solid waste \\
\hline Drill pipe & Salvageable if in good condition \\
\hline Drilling mud & Pre-1975 contained asbestos, barium, chromium \\
\hline Drums or barrels (empty) & Ordinary waste \\
\hline Drums or barrels (not empty) & Hazardous or salvageable \\
\hline Epoxy tar sites & Ordinary waste \\
\hline Eye hook tie downs & Salvageable \\
\hline Fencing & Ordinary waste \\
\hline
\end{tabular}


Table A-1

Page 19 of 30

\section{Waste Ciategorization List} (Page 2 of 3 )

\begin{tabular}{|c|c|}
\hline Waste Type & Possible Waste Category \\
\hline Fluorescent light bulbs, intact & May be hazardous; not housekeeping if broken \\
\hline Food containers, food wrappers & Ordinary waste \\
\hline Gas cylinders (compressed) - empty & Salvageable \\
\hline Gas cylinders (compressed) - not empty & Hazardous or salvageable. \\
\hline Gas cylinders (uncompressed) & Can be reused if in good condition \\
\hline Gasoline cans & Salvageable \\
\hline Glass & Ordinary waste \\
\hline Heavy equipment & Salvageable \\
\hline Hoists, pulleys & Salvageable \\
\hline Hoses & Salvageable if new and/or in good shape \\
\hline Industrial solid waste & Salvageable or ordinary waste \\
\hline Joint compound & May be hazardous \\
\hline $\begin{array}{l}\text { Lead (batteries, sheets, shielding bricks, shot, } \\
\text { paint) }\end{array}$ & Recyclable, hazardous, or mixed \\
\hline Linoleum & Asbestos potential. \\
\hline Liquids & Sample; not housekeeping. \\
\hline Lumber, dimensioned & Salvageable - \\
\hline Mastic & May contain asbestos \\
\hline Metal (scrap) & Ordinary waste \\
\hline Metals (steel, iron, aluminum, copper) & Scrap or ordinary waste \\
\hline Nuts, bolts, nails & Salvageable or ordinary \\
\hline Office trash & Ordinary waste \\
\hline Organics & Not housekeeping \\
\hline Paint cans & Probably not hazardous if latex \\
\hline Painted or treated wooden boards & May be hazardous \\
\hline Pesticide cans & Hazardous even if empty \\
\hline Petroleum'spill sites (< 3 cubic yards) & Hydrocarbon waste \\
\hline Photographic equipment & Salvageable or recyclable \\
\hline Photographic chemicals & May be hazardous \\
\hline Pipes and unions & Salvageable \\
\hline Piping or connectors with insulating wrap & Asbestos potential \\
\hline Piping with sealant on the threads & Sealant is often lead based \\
\hline Plastic, molded & Ordinary if not new or re-ussable \\
\hline Rebar & Salvageable \\
\hline
\end{tabular}


Page 20 of 30

\section{Table A-1 \\ Waste Categorization List (Page 3 of 3 )}

\begin{tabular}{|c|c|}
\hline Waste Type & Possible Waste Category \\
\hline Recyclable Materials & $\begin{array}{l}\text { Cabling, steel, drill pipe, empty gasoline cans, } \\
\text { empty gas cylinders, nuts and bolts }\end{array}$ \\
\hline Sand bags & Salvageable or ordinary waste \\
\hline Signs & Salvageable if metal or plastic and in good condition \\
\hline Silver & Photographic related; not housekeeping \\
\hline Spill sites of known materials, (<3 cubic meters) & Hazardous or ordinary \\
\hline Soil that contains lead shot & Not housekeeping; requires treatment \\
\hline Soil contaminated with metals or organics & Such as lead or solvents; not housekeeping \\
\hline Sparkletts ${ }^{\top M}$ bottles & Returned for deposit \\
\hline Spray insulation & Ordinary waste \\
\hline Stained soil & Probably not housekeeping \\
\hline Sulfa-set & Ordinary waste \\
\hline Tar & Ordinary waste \\
\hline Tin cans & Ordinary waste \\
\hline Tires & Salvageable or recyclable \\
\hline Transformers/polychlorinated biphenyls (PCBs) & Toxic; ordinary waste if less than 1 gallon \\
\hline Transite pipe & Non-metal, non-plastic pipe; asbestos potential \\
\hline Trash cans, metal & Salvageable if in good condition \\
\hline Treated or painted pallets or posts & May be hazardous \\
\hline Unexploded ordnance & Not housekeeping \\
\hline Tiles and shingles - roofing, flooring, and ceiling & $\begin{array}{l}\text { Asbestos potential; ordinary waste if nonfriable; not } \\
\text { housekeeping if friable }\end{array}$ \\
\hline Wallboard & Paint and asbestos potential \\
\hline White plastic sheeting & $\begin{array}{l}\text { May be used if new or non-weathered; otherwise } \\
\text { ordinary waste }\end{array}$ \\
\hline Wood - bare & Ordinary waste \\
\hline Wood - cable spools, pallets & Salvageáble \\
\hline Wood - dimensioned lumber & Salvag̀eable \\
\hline Wood - painted or treated & May be hazardous \\
\hline Wood railroad ties (untreated) & Ordinary waste \\
\hline Wood railroad ties (treated; creosote) & Hazardous \\
\hline
\end{tabular}

Note: Anything that could contain metals or organics or that could have been contaminated with metals or organics may be hazardous waste. Items contaminated solely with certain petroleum hydrocarbons are not hazardous waste but must be disposed of in a hydrocarbon landfill or in a special section of a SWDS. Process knowledge or sampling must be used to determine how the hydrocarbons are regulated. If sampling is required, the site is not housekeeping. 
Housekeepıng CAU Work Plan

Revision: 0

Date: 08/19/96

Page 21. of 30

\section{Appendix B}

\section{Housekeeping Category Logic Diagrams}




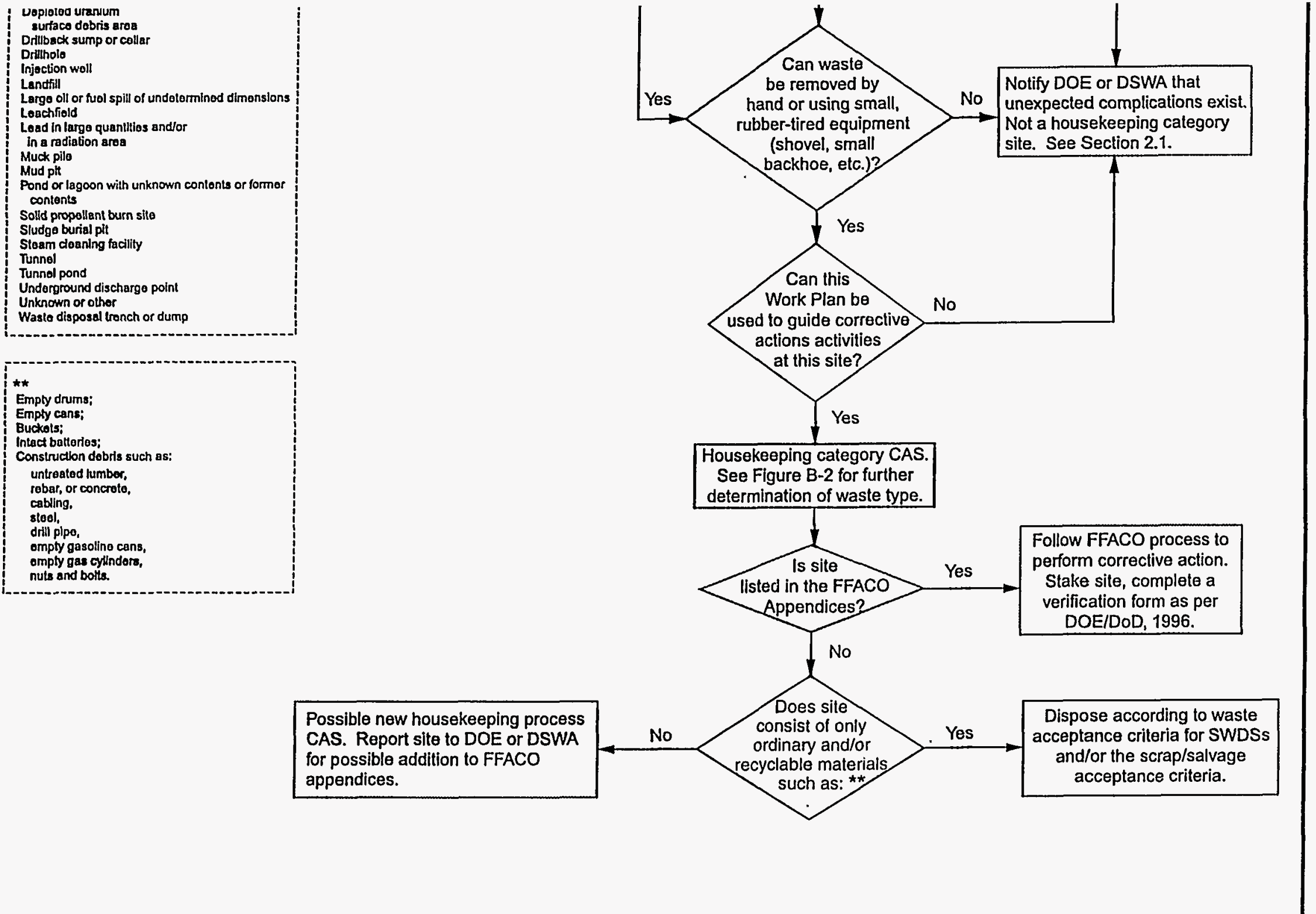

Figure B-1

Logic Diagram for Determination of Housekeeping Category Corrective Action Sites 


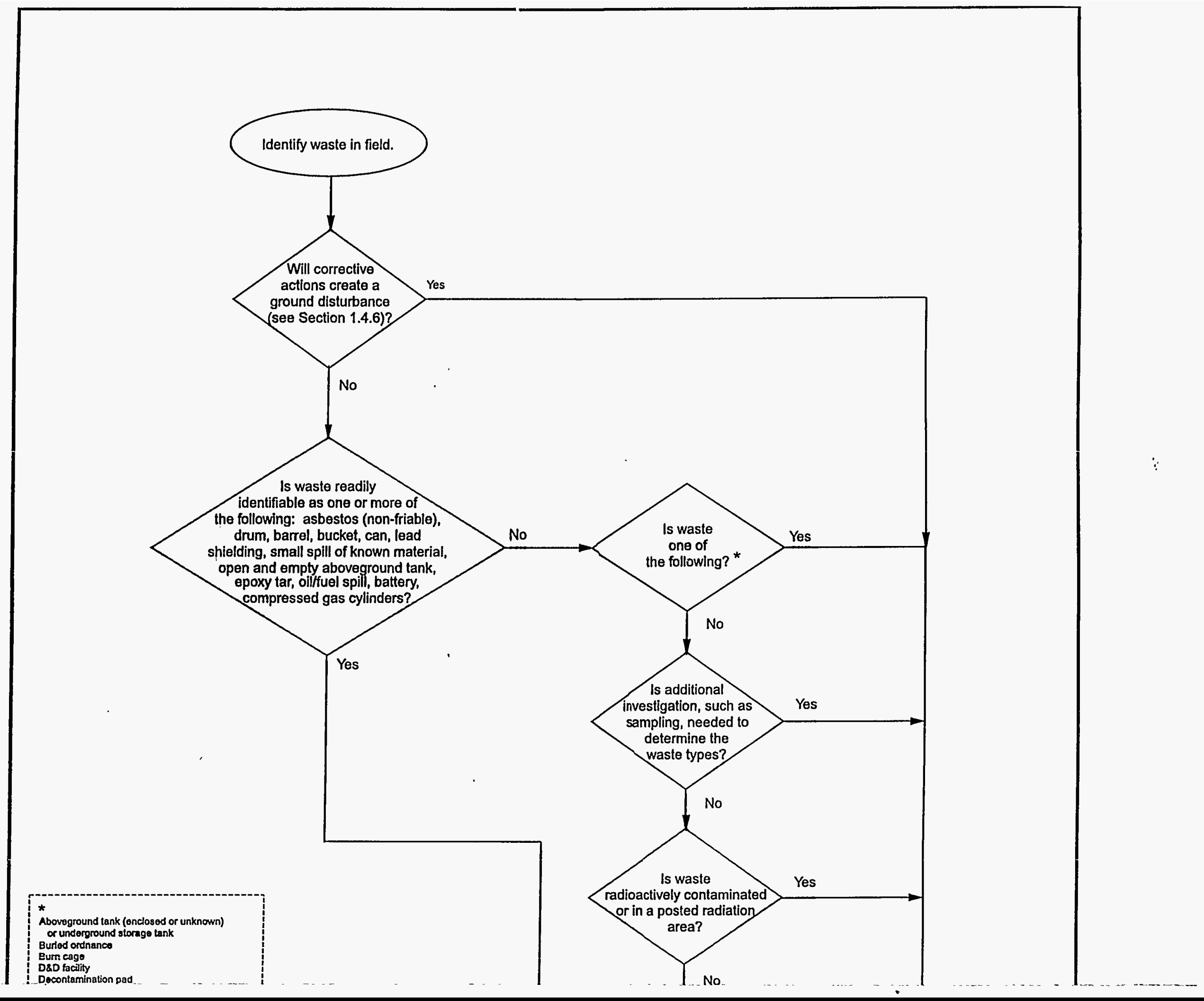




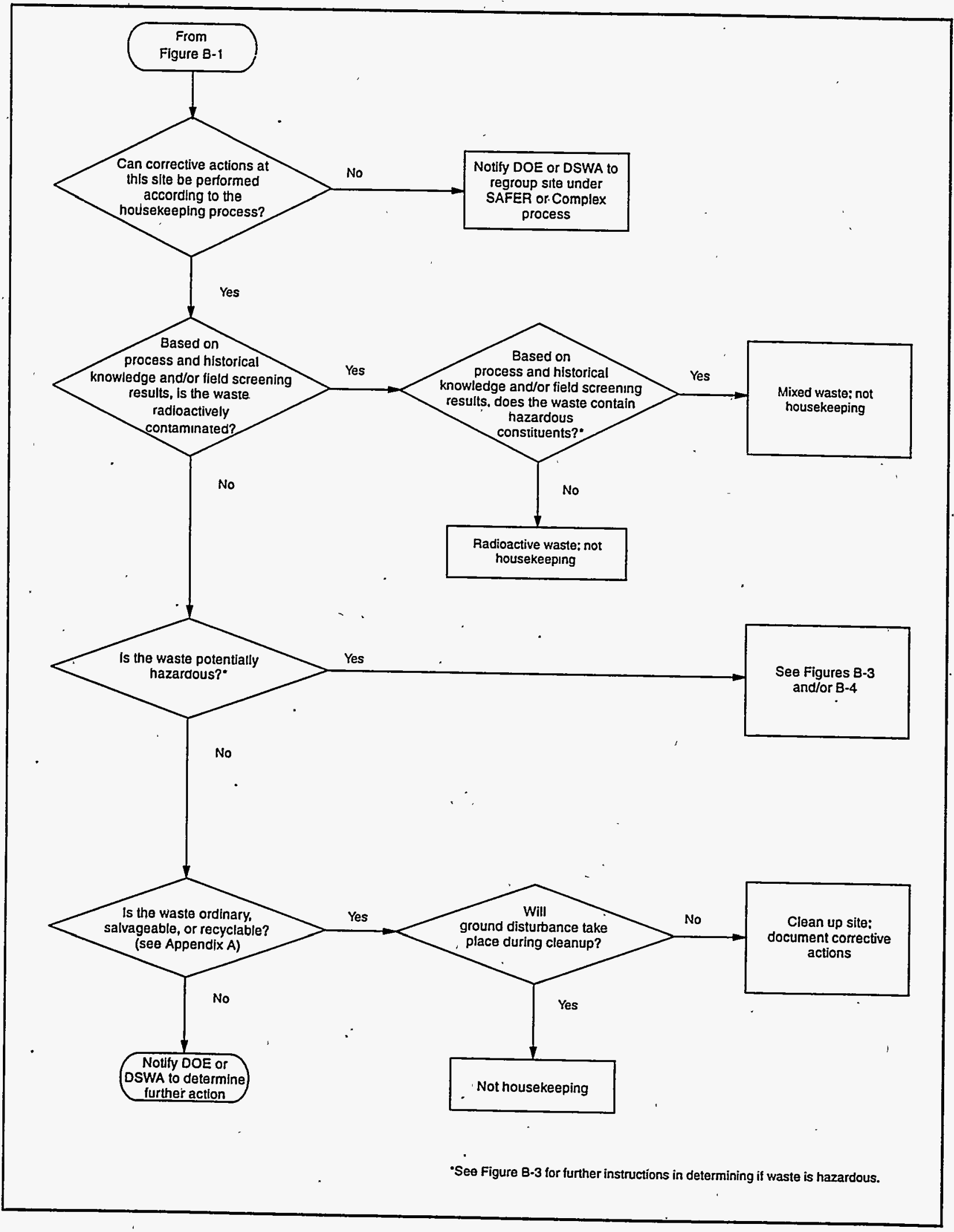

Figure B-2

Logic Diagram for Determination of Waste Category 


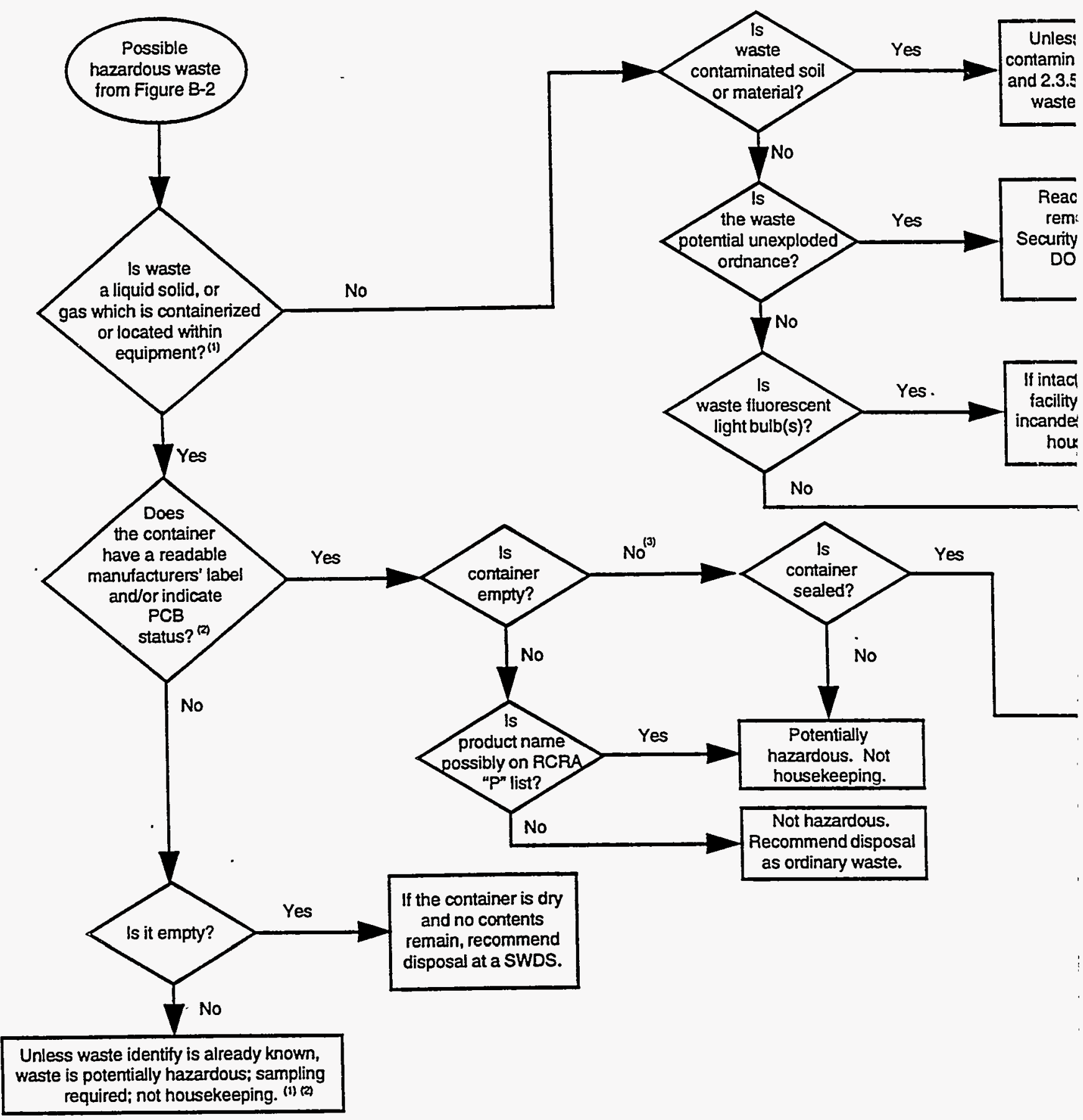

(1) Such as drums. buckets, cans, aerosol cans, pressurized compresessed gas cylinders, transformers

(2) For electrical equipment, if not labeled "non-PCB" or "PCB," assume potential PCB waste. For transformers on NTS, transport to transfe

(3) For aerosol cans. check for starting fluids and other ether fluids; not housekeeping. 
s small spill of known

ants (see Sections 2.3.4

i). potentially hazardous Not housekeeping.

tive hazardous waste. Do not touch, move, or ove the waste. At NTS, immediately report to

- Control (5-3881), DOE Site Security (5-0082), or

E Radiological Operations (5-4015). At TTR, immediately report to $5-8109$.

6. recommend sending to crushing

- If broken, not housekeeping. If scent with lead, drum as recyclable sekeeping waste or lead scrap.

Waste is not hazardous. Recommend disposition as ordinary or salvageable waste. Clean-up if ground disturbance is not required. If ground disturbance is required, not a housekeeping site.

If MSDS is available, may be characterized through process knowledge: otherwise not housekeeping. 


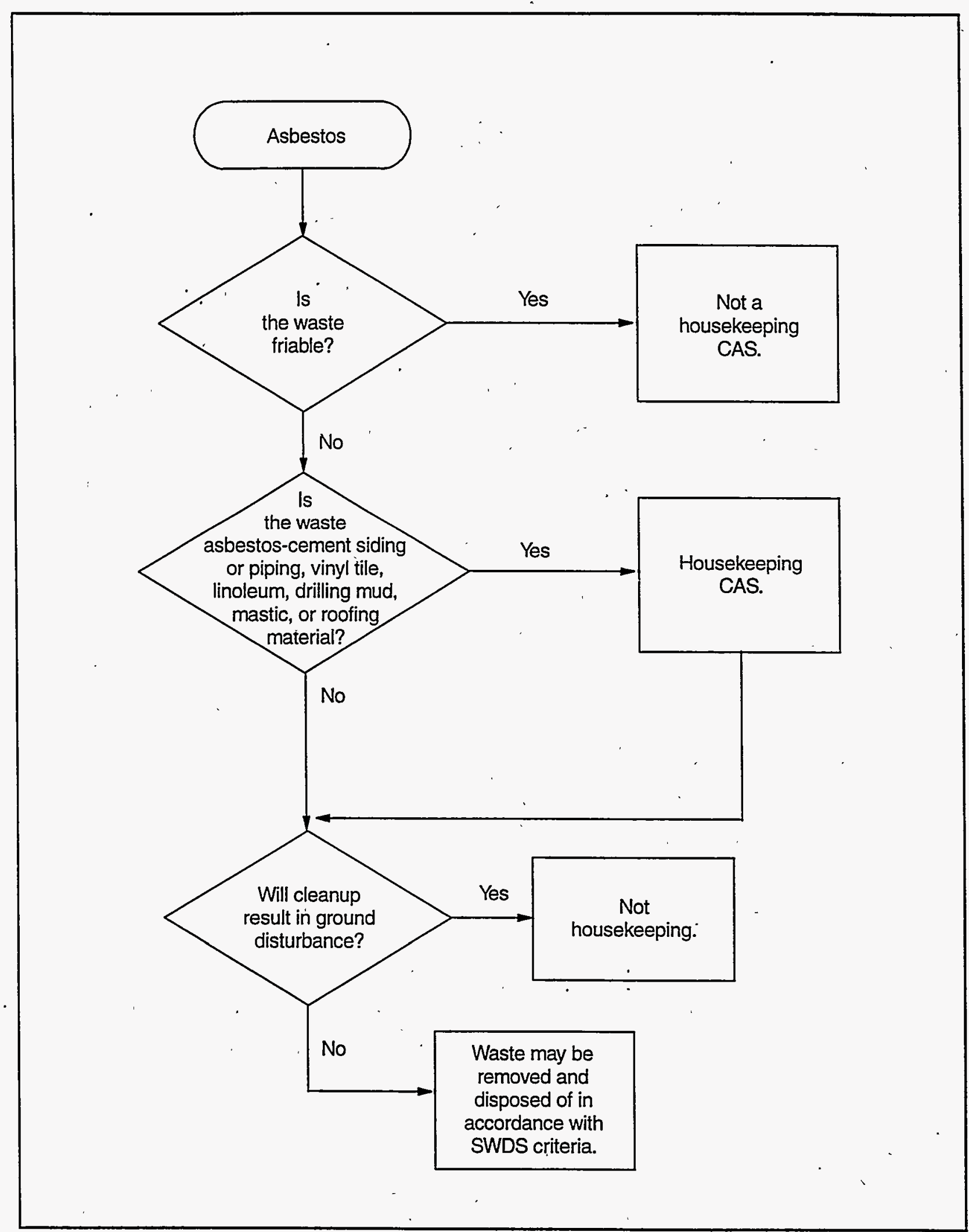

Figure $B-4$ 


\section{Appendix C}

Example of a Housekeeping Category Corrective Action Documentation Form 


\section{HOUSEKEEPING CATEGORY CORRECTIVE ACTON DOCUMENTATION FORM}

CAS Number:

Date of Site Visit:

If not an identified FFACO Appendix site, enter driving instructions (include access and health and safety restrictions:

\section{Field Clean-up Personnel:}

Field Verification Team:

RCT:

Labor Crew:

Waste Management Personnel:

Others (name, affiliation, title):

Describe Waste ltems. Indicate (R) Removed, or (NR) Not Removed. If NR, explain:

Waste Item List:

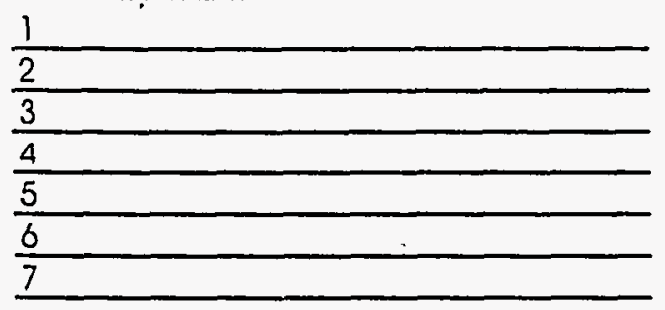

Site Photograph(s) Taken?:

If yes, list photograph numbers and subjects:
Waste Category: (Ordinary. Salvageable. Recyclable. etc.). .

$R / N R$
$R / N R$
$R / N R$
$R / N R$
$R / N R$
$R / N R$
$R / N R$

Yes

No

No

If yes, describe results:

Is sampling needed?:

No Yes

(If yes, describe):

Waste will be taken to:

Waste Disposal Information:

Is this the final disposal location?

Yes

No

If no, describe future disposal process:

\section{Waste Manifest Number:}

On-Site:

Off-Site:

\section{Comments:}




\section{Distribution List}

(Page 1 of 3)

U.S. Department of Energy

Copies.

Office of Scientific and Technical Information

2 (uncontrolled)

175 Oak Ridge Turnpike

Post Office Box 62

Oak Ridge Tennessee 37831

DOE/Nevada Operations Office

Technical Information Resource Center

P.O. Box 98518

Las Vegas Nevada 89193-8518

Mr. David Shafer

Acting Project Manager

Environmental Restoration Project.

DOE/Nevada Operations Office

Ms. Sabine T. Curtis

Acting Industrial Sites Subproject Manager

DOE/Nevada Operations Office

Mr. Clayton Barrow

Industrial Sites Subproject Assistant Manager

DOE/Nevada Operations Office

Ms. Sabrina Bonnell

Environmental Restoration Division Records Center DOE/Nevada Operations Office

1 (3 uncontrolled)

Mr. Dave Bedsun

Defense Special Weapons Agency

Las Vegas Nevada

Mr. Wayne Griffin

Bechtel Nevada

Las Vegas Nevada 


\section{Distribution List}

(Page 2 of 3)

\section{Copies}

Mr. Paul J. Liebendorfer

Nevada Division of Environmental Protection

Carson City Nevada

Mr. Jerry Sieren

Nevada Division of Environmental Protection

Las Vegas Nevada

Mr. Carlos Gonzales

Bechtel Nevada

Las Vegas Nevada

Mr. Dave Schlick.

Bechtel Nevada

Las Vegas Nevada.

Mr. Ken Beach. Project Manager-

IT Corporation

Las Vegas Nevada

Mr. Richard A. Dubiskas, Technical Lead

IT Corporation

Las Vegas Nevada

Ms. Sharon Jacobson

IT Corporation

Las Vegas Nevada

Ms. Bonnie Blake

IT Corporation

Las Vegas Nevada

Ms. Angelica Russell

IT Corporation

Las Vegas Nevada

Ms. Cheryl Prince

IT Corporation

Las Vegas Nevada 
Distribution List

(Page 3 of 3 )

\section{Copies}

Ms. Cindy Dutro

IT Corporation

Las Vegas Nevada

Mr. Don Cox

1.

IT Corporation

Las Vegas Nevada

Ms. Barbara Deshler

IT Corporation

Las Vegás Nevada

1 (uncontrolled)

Ms. Pam Adams

IT Corporation

1 (uncontrolled)

Las Vegas Nevada 